\title{
Sustaining Economic Development by Reforming Basic Institutions through Community Participation
}

\author{
USMan Mustafa and M. AfZAL Mir
}

\section{INTROUDCTION}

It is universally accepted and advocated that without community involvement and participation, development initiatives either in the economic or social sector, have little chances of success/sustainability, especially at the grassroots level, where the majority of the country's population lives [AKRSP (1984, 1999); FAO (1989); Khan et al. (1984) and Mustafa (1998)]. In this connection the concept and approaches of community development have been tested in Northern Areas of Pakistan and the principles and experiences have been replicated in some other parts of the country by Non Government Organisations (NGOs), different national and international government projects and programmes [Mustafa and Grunewald (1996); NRMP (1993) and NRSP (1995)]. The need for conceptualising a realistic framework for collaboration between government/other development agencies and community organisations engaged in pursuit of both social and economic goals is imperative for an equitable and sustainable development because when it comes to community involvement, the two sectors cannot be divorced from each other [Khan (1999) and Reid and Khan (1996)].

The objectives of the paper are: to highlight the need and the importance of grassroots non-government institutions based on participatory community development approaches; to analyse the role of community participation models in the country and to recommend strategies for an effective linkage between grassroots non-government organisations and basic-services-driven government institutes for effective and sustainable development; also to review and recommend primitive structural changes in basic institutions as development partners.

Usman Mustafa is Monitoring and Evaluation Specialist and M. Afzal Mir is Social Mobilisation Specialist at Area Development Programme (ADP)-Extension Services Management Academy (ESMA), United Nations Development Programme (UNDP), Garhi Dopatta, Azad Jammu \& Kashmir. 


\section{METHODOLOGY}

Participatory Rural Appraisal (PRA) technique was adopted to achieve the objectives of the paper. In this connection Semi Structure Interview (SSI), Direct Observation, Key Informant Survey, Secondary Sources of Information, Problem Causes Diagram, etc. were used as tools of PRA.

The first part of the paper deals with the introduction of participatory community development approach. The role of NGOs, in developing community groups (DCGs) was also covered under this part. The second part discusses community participation models in the country including the community development approaches tested in government projects/programmes and lessons learned to recommend basic reforms. The third and the last part of the paper highlights the issues, alongwith some strategies and recommendations for reforming basic institutes for sustainable economic development.

\section{INTRODUCTION TO PARTICIPATORY APPROACHES}

Past development experience has proved that if people have opportunities to participate in the decision-making process, have access to management of their own individual and common resources, the process of development is socially acceptable and viable, economically feasible and efficient which results in its sustainability. This orientation is based on an organisational approach to development with institutional capacity building at the community level which is the focal point. A participatory methodology helps:

1. Organise community institutions based on people's identified needs;

2. Increase awareness and up-gradation of their people's indigenous skills (human resources development);

3. Capital formation (saving and credit); and

4. Develop effective linkages with line agencies (Govt. and NGO).

The Social Guidance Approach (SGA) is performing a front line pivotal role in the implementation of programmes for sustainability, equitable and increased productivity within scarce resources, gender focusing and helping the poorest among the poor.

Following are the basic principles of SGA:

1. Willingness to help themselves (Self help).

2. Willingness to identify honest and democratic leadership.

3. Willingness to identify the poorest from amongst them and to address their priority needs.

4. Willingness to identify economic activities and social sectors. Honest and democratic leadership. 
Communities were traditionally participating on adhoc basis in narrowly focused areas i.e. labour contribution for harvesting, houses or social services buildings construction, repair or renovation of social institutions, etc. depending upon environmental and geographical distribution of hamlets/areas. The new concept of community participation focuses on specific infrastructure projects, project formulation, implementation and maintenance, monitoring and evaluation, training and supplies programmes, saving and loan transaction and participatory management of natural resources, skills, capital and other resources [Awan (1999); FAO (1993) and Khan (1999)]. This way it builds self-confidence and empowerment in the community's members in development group strategies to solve their problems and to improve the standard of living [NRSP (1995)].

Evidence indicates that if both men and women are active participants in the development process as definers of desired change and leaders of activities within their communities, development is more effective. Democratisation of the development process means adoption of local development approach based on innovation, testing, assessment. It also means changing cultural values from passive acceptance of authority and change towards self-reliance and development.

The core concept of participatory approach is establishing a local development agency through the formulation and capacity building of basic institutions or community development groups (CDGs) or Community Organisations (COs). CDGs build basic management cadres, foster cooperation and enable problem identification and solution at the grassroots level. Through CDGs, individuals articulate their own and group needs, plan survival strategies, and create an independent local entity which functions democratically and develops its own initiatives and demands.

Dr Shoaib Sultan Khan, first GM of AKRSP, in his concept paper about the development of a grassroots institute describes community participation as under [Khan (1990)].

"Community Participation means broad-based, decentralised, homogenous organisations at the village and neighbour level. Broadbased and homogenous means that membership extends to, and decision-making is done by, all those common economic interest is best served by working together. Decentralised means that decision-making is the responsibility of local communities; supporting agencies, like government and other development agencies, provide technical and financial assistance, but they do not infringe upon the sovereignty of the community organisation. In other word, community participation ensures development of, for and by people".

A particularly important example of participatory management is the implementation and maintenance of Productive Physical Infrastructure (PPI) projects and the subsequent planning that might be needed to exploit the opportunities opened 
up by such projects [AKRSP (1999)]. Uncultivated barren land opened up by an irrigation channel, for instance, needs to be divided among the villagers, apportioned into different uses, development into cultivable land, planted with appropriate crops or trees and then cultivated with the help of productive inputs. The output, then, has to be marketed profitably [AKRSP $(1984,1999)$; Khan and Hussain (1984); NRMP (1993); LIFE (1998)].

\section{RATIONALE FOR COMMUNITY DEVELOPMENT APPROACH}

Community institution building is based on certain assumptions [AKRSP (1984); Khan and Hussain (1984); NRMP (1993) and Ikramullah (1999)]:

- Government resources are not infinitely expandable. As population increases and puts further pressure on a limited ecological base, government services become in sufficient for meeting basic needs and fostering development. With local grassroots institution building, communities take more responsibility for meeting basic needs and learn to set priorities for receiving government assistance. Subsequently, government's recurrent expenditure is reduced, services get more specialised and technical inputs are more easily disseminated at a lesser cost.

- There is a big gap between government institutions and the beneficiaries, resulting in inadequate development.

- A number of foreign and government-assisted projects, implemented under the conventional approach without people's share and involvement result in dependence on government or donor agencies.

- Poor and ineffective delivery of services to end-users.

- The poor and uneducated have less access to interventions by government at a quality level. They do not know how to demand services from the government (or even private sector), and have lower trust in government institutions. CDGs provide a forum to this section of population to gain greater access to and demand quality services from government.

- Local level conflicts and political polarisation are creating hurdles in hastening the development process.

- Community groups define their needs, rank them, improve their managerial and technical skill, enhance their income; they are more likely to sustain their resources.

- The community economic development activities are sustainable. The community working is based on participatory principle for the good of all the members.

- Government rules and regulations are not effectively observed as of local/community based decisions. 
The advantage of participatory development are multifold. It is not only cost effective, timely, increases the empowerment and is watchful of the interest of the community, increases the income and standard of living etc., but also provides an entry point to other socio-economic activities. The basic democratic institutions are strengthened with strong participatory monitoring and evaluation that not only boosts production but also eradicates corruption. (Figures 1 and 2).

\section{COMMUNITY DEVELOPMENT EXPERIENCE IN PAKISTAN}

The community development approach with special reference to grassroots institutional development was initiated in Pakistan by The Agha Khan Rural Support Programme (AKRSP) in the mid-1980s, and since then has been replicated and modified by a number of other NGOs, to suit their own specific environments. The government and donor agencies have been playing a pivotal role in community development along with NGOs.

\section{The Agha Khan Rural Support Programme (AKRSP) Model}

The AKRSP is an NGO, which operates in three locations in Northern areas and Chitral. It was the first organistaion to adopt the principle of encouraging rural and agricultural development through a community approach. The underlying theme of AKRSP is to support community based grassroots development to build capacity of the local people to sustain and improve the quality of their lives. It is funded by a number of international donors. Its major programme components include social organisation, women's development, natural resource management, and development of productive physical infrastructure, human resource development, enterprise promotion, credit and saving services and monitoring, evaluation and research.

The main approach of AKRSP has been to focus on helping small farmers to farm Village Organisations (VOs), which are broad-based multi-purpose structures through which development activities are undertaken. A total of 3,557 VOs have been formed that included 1,258 women organisations up to 1998 (3). This covers 84 percent of rural households under the VOs. Savings play a key role, and through these Vos are able to obtain credit from AKRSP. Total savings of Rs 414,45 million and Rs 1,131.24 million credit had been disbursed among 538,052 households up to 1998. The loan to saving ratio was 0.76 up to 1998. Training of village representatives in various skills is a third key principle. The total development cadre of village specialists/activists was 22, 796 up to 1998 [AKRSP (1999)]. Summary of the progress is presented in Table 1.

The field units which help in the organisation of VOs are called Social Organisation Units, and it is the Social Organiser (SO), who is in-charge of the unit, who has played a key role in forming groups and helping them to operate effectively. SOs visit villages, talk to people and help form a VO, which is encouraged by 


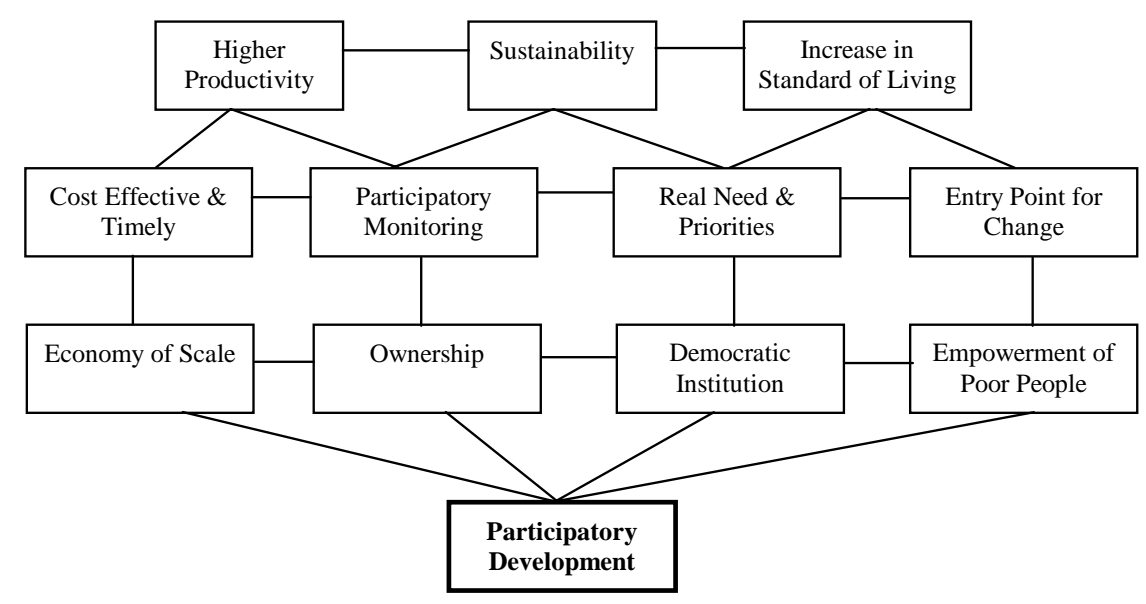

Fig. 1. The Advantages of Participatory Development.

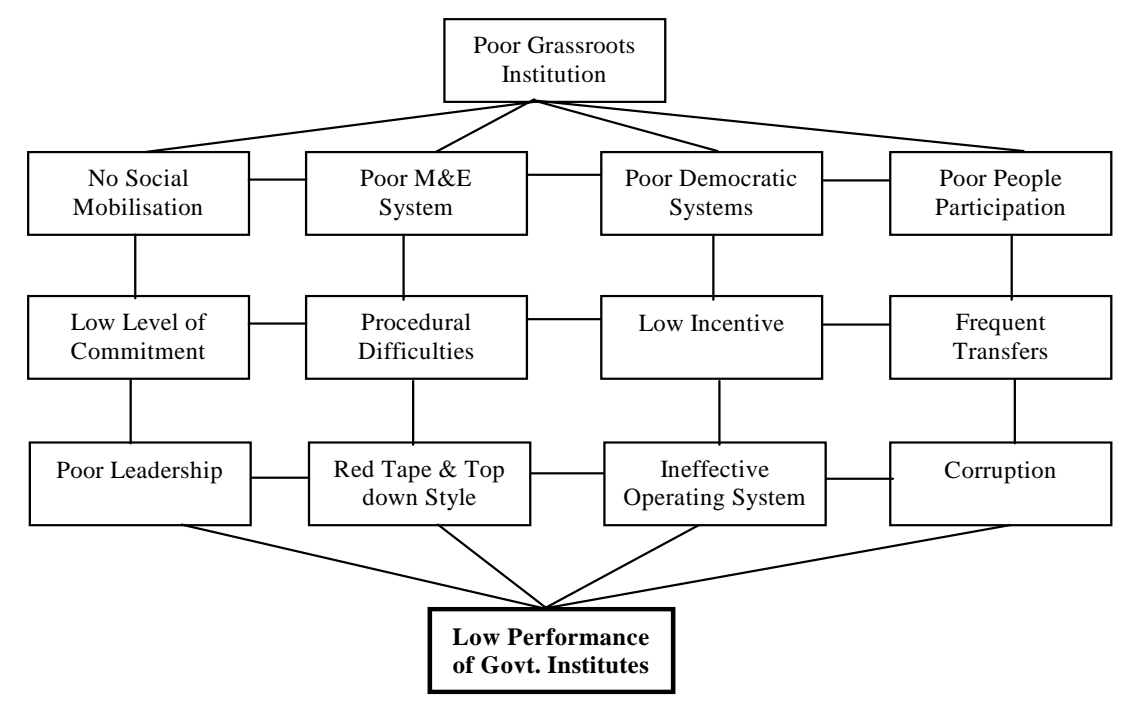

Fig. 2. Problem and Cause Diagram for Low Performance of Government Institutions. 
Table 1

\begin{tabular}{lrrr}
\multicolumn{4}{c}{ Cummulative Statistical Abstract of AKRSP, SRSC and NRSP } \\
\hline Activities & AKRSP & SRSC & NRSP \\
\hline No of Districts & $(1998)$ & $(1997)$ & $(1998)$ \\
Rural Households (Nos.) & 7 & 7 & 22 \\
Social Organisation (Nos.) & 116,335 & 575,354 & $25,511,074$ \\
\% of Rural Households Covered by SO & 3,557 & 1,680 & 5,873 \\
Total No. of Members & 84 & 10 & - \\
Average Size of an Organisation & 133,856 & 54,964 & 132,247 \\
Total Saving (Rs Mil) & 38 & 33 & 23 \\
Disbursement of Loans (Rs Mil) & 414.45 & 20.34 & 115.21 \\
\hline
\end{tabular}

conducting an initial survey for Productive Physical Infrastructure project (PPI). This is often a road or a bridge or some income generating project which is funded by a grant from AKRSP. Subsequent to this, a savings programmes and training of representatives is developed through the VO. The main difficulty in organising VOs lies in finding committed personnal to serve as SOs. [AKRSP $(1984,1999)]$.

The role of the AKRSP in the formulation of grassroots institution has been highly remarkable. Over all 84 percent of rural households have been covered by village organisations (Table 1). Although in a number of discipline/programmes the line agencies are playing their role but still there is a need to strengthen the line departments for effective delivery of services to the community.

\section{The Sarhad Rural Support Corporation (SRSC) Model}

The SRSC is an NGO established during 1989 and funded by USAID, IFAD, and ADB. It operates out of Peshawar, and covers four regions i.e. Charsadda, Mansehra, Kohat and Abbottabad covering seven districts in NWFP [SRSC (1998)]. It has the mandate to support line departments within its areas of operation. SRSC has the task to organise and strengthen community organisation, and coordinate line departments. It sees itself as an interface between rural people and the various faces of government.

Like AKRSP, it has a community rural development focus. The key focal point is the village group. These are called Village Organisations (VOs), Community Organisations (COs), and Women's Organisation (WOs). It is principally the work of social organisers within SRSC to form these groups. Upto 1997 they were operating through 1,680 groups with 32 percent women and 19 percent of the target rural households (Table 1). The corporation has total savings of Rs 20.35 million, loans disbursed of Rs 42.46 million with 75 percent recovery rate [SRSC (1998)]. 
In theory, the field staff of government departments is supposed to co-ordinate with VO activities. In practice this is not happening due to a number of reasons.

\section{The National Rural Support (NRSP) Model}

NRSP is a professional programme, managed as an NGO and overseen by a board of directors. Its strategy has been evolved over a number of years in which it has been working, since 1991. It operates in every province of Pakistan and in AJK.

The basic conceptual features are the same as AKRSP, but NRSP claims to have evolved adaptations that are relevant to the areas in which they are working. NRSP mobilises villagers into Community Organisations (COs), that become a main vehicle for local development. As with most community development organisations they insist on savings, which form the basis for subsequent credit arrangements from NRSP.

In additional to the Social Organisation sector, NRSP maintains these components: Natural Resource Management, Human Resource Development Physical Infrastructure and Technological Development, Social Sector Services, Rural Credit and Enterprise Development and Monitoring, Assessment and Planning. NRSP has attempted to set up an Urban Poverty Alleviation Model in Pakistan in order to test its suitability in catering to the needs of the urban poor. This Project has the backing of the government and is financially supported by UNDP. The Grameen Bank and the credit programme of the Orangi Pilot Project is the inspiring model behind this project. There is a substantial rapid expansion in the programme. The funds have increased by 144.6 percent from 1997-98 to 1998-1999 i.e. from Rs 679 to 1,661 millions [NRSP (1999)].

The cumulative figure of COs formed at the end of June 1998 was 5,873 including 1,395 female and 4,000 male while the rest were mixed. The total savings and collateral of the entire COs was Rs 1,15,206,739. Total credit disbursed up to June 1998 was Rs 6,80,878, 491 amongst 40, 103 loaners. The average credit per loaner was Rs 16,978 (Table 1). Out of the total due amount of Rs 286.3 million as of June 30, 1998, a total of Rs 274 million was recovered which was 96 percent of the due amount [NRSP (1999)].

\section{Area Development Programme (ADP) of UNDP and other Foreign Assisted Project}

The GoP-UNDP Country Cooperation Framework (CCF) envisages addressing the issue of poverty eradication and sustainable human development through three programme areas that include governance, gender and sustainable livelihoods.

Each of these thematic programmes is to be build on four elements: capacity building, alliance building, resource mobilisation and support to advocacy activities. 
Succeeding the current Fifth Country Programme, the CCF will cover the period from July 1998 to June 2003 [UNDP (1998)].

Drawing on the guidelines and primary focus of the GoP/UNDP approach, espoused in the CCF, the Area Development Programme, Balochistan, AJK and Chilas, Northern Area while focusing on sustainable livelihoods programme has incorporated key elements of governance, gender empowerment and linkages towards strengthening community-government relationships [ADP-AJK (1997); ADP-Balochistan (1998) and UNDP (1997)]. The target communities to benefit from the programmes are the resources-poor rural people. One of the main targets of the programme is to promote people's participation through formal communities.

Similarly, there are a number of foreign assisted projects and programmes operating in the country with emphasise community participation. The sustainability of the projects remains the major issue after their termination. The community organisations were provided with certain incentives or basic amenities of life.

\section{Orangi Pilot Project Karachi (OPP) Model}

OPP is one of Pakistan's finest self-help institution. It is an urban environment protection, health and sanitation improvement and housing development model based on participatory approach developed by late Khan (1999). The project initiated its work by a diagnostic survey to identify community problems. The problems identified were: housing and sanitation, health, education and unemployment. The working style of OPP is that people do the inside work themselves and then ask government to do the outside work. People themselves do the streets, sewerage maintenance etc. while the main drainage and sewerage treatment plants are developed and installed by government. The basic principle of OPP is to hire a few people on small salaries. The project developed indigenous, cost effective and sustainable technologies [LIFE (1998)].

The project during 1981 and 1998 completed 6000 streets without any foreign assistance. The OPP's housing and sanitation programme has brought about major environmental changes, and at no cost to the government. Over 80 percent of Orangi Township has built its own sanitation system. Due to the sanitation system and the OPP's health programme, infant mortality has fallen from 130 per thousand in 1984 to 37 in 1991. In the same manner the Orangi schools, without any assistance from the government or external resources, have raised the literacy of Orangi residences to over 78 percent as against an estimated Karachi average of 62 percent [Hassan (1999) and LIFE (1998)].

\section{Government Participatory Development Programme (PDP)}

Participatory Development Programme (PDP) was launched in 1995-96, as a pilot community development programme under the Social Action Programme 
Project Phase I (SAPP-I) to deliver social services to the deprived communities and indigent segments of the society, especially women and children. Under PDP, a group of 28 NGOs from all provinces/areas with 30 innovative projects were launched [Pakistan (1999)]. The experiment of establishing linkages at grassroots under PDP has been successful. It helped to empower communities in identification and planning of schemes, decision sharing and management of service delivery in a tripartite partnership by combining the government, private sector represented by NGOs and beneficiary communities . The government's role was to define policy goals and arrange support funding while the NGOs were to motivate communities for participatory development [Pakistan (1999)].

However, sustainability of PDP projects remains doubtful. The sustainability issues were examined by focusing on each NGO as follows [Pakistan (1999)]:

(i) Sustainability of the NGO itself.

(ii) Sustainability of the sub-organisations which the NGO's formulated at grass-roots level.

(iii) The sustainability of the projects which the NGO's were implementing.

This three-stage examination had shown that the sustainability of the NGO's initiatives after the end of the PDP was highly variable, as communities had not been properly involved. However, most of the PDP's/NGO's water supply schemes which had been undertaken by following the basic community participation principles, would generally be sustainable. After the completion of SAPP Phase-I (1993-96), government has launched the five years (1997-2002) SAPP Phase-II project with a budget of Rs 498.8 billion with a major share of provinces (87 percent) and only 13 percent share of federal government. The major provincial share in financing also reflects that SAPP components are basically provincial subjects. The Phase-II also focuses on five priority areas i.e. primary/elementary education, primary and preventive health care, nutrition, rural water supply and sanitation and family planning. The actual expenditure of SAPP-I and projected outlays of SAPP-II Pakistan (1999) show a big increase of 369 percent in the allocation of funds for SAPP-II.

\section{ISSUES, CONCLUSIONS AND RECOMMENDATIONS}

The reforming of basic institutions through community participation is to build around the social mobilisation approach. Under this approach communities are organised at grassroots level by the formulation of both male and female Community Development Groups (CDGs). The CDGs are organised to help people take charge of their own affairs and achieve self-reliance for sustainable and equitable development. It is important that people should be involved in the development work at all the stages. If the themselves can not do anything, no one can else do anything 
for them. These groups should be organised on the principle of social guidance and participatory approach. Through the forum of the CDGs there should be a community-based development of the area resources. The beneficiaries are facilitated in the adoption of tested technologies, enterprises and skill enhancement, on the basis of their felt needs. In the formulation of CDGs both government and NGOs are playing their role. There should be a clear guideline for the role of NGOs, government, implementing agency or a facilitating one or a combination of both. NGOs should not be limited to only "delivers of development services". Rather, they should be seen, indeed encouraged, as an expression of robust and dynamic civil society. And it is an essential pre-condition for the development of prosperous, equitable and sustainable country. Under the corrupt, unjust and ineffective system these are the last hope of national development. The role of NGOs should not be to develop a parallel government department. Similarly, government can construct schools and basic health centres as done in SAP and other donor assisted projects but these are mainly limited to building and cannot be operative until and unless there is an active participation of people or communities. The people should do the internal or small construction work or CDGs by themselves while the outside work is to be done by government. For example CDGs should complete small streets, sewerage, water supplies pipes, etc. while the roads, big sewerage, water treatment plants, etc. should be the job of government. There are thousands of NGO operating in the country. Out of these very few are working in a real sense. An NGO is defined as a non-profit organisation outside of government establishment working for a public (culture, social, humanitarian or development) purpose with a voluntary governance structure.

The CDG (grassroots institutions) formulation work can best be done by NGOs as under the government top-down hierarchy this would be very difficult. In some donor assisted projects government departments have been able to establish good CDGs but only up to the project life. Their sustainability can only be ensured if they are linked to some well-established organisation or NGO. The role of grassroots institution development by AKRSP, NRSP, SRSC and some other NGOs is commendable. There is a need to expand their area and operations but their primary focus should remain on development of grassroots institutions providing guidelines and strengthening the linkage between government and the CDGs. The community development work is very slow, it requires patience, the understanding of the basic concept of self-help and participation is very much needed for sustainability.

Given the inevitable growth and expansion of the Rural Support Programme concept to other parts of Pakistan i.e. Sindh and AJK, major new funding opportunities are likely to materialise. In this connection special priorities should be given, in helping train Social Mobilisation Officers. For effective mobilisation, and support of communities, investing funds in a way that contributes to long-term sustainability e.g. through the endowment mechanism and providing funds to address 
credit needs that cannot be satisfied through existing facilities is necessary. Intensive field supervision, result-based participatory monitoring and evaluation will be needed. Programme emphasis should focus on the productivity and profitability of credit supportive enterprises and on the equitable sharing of the benefits. There is also a need to have a memorandum of understanding between the GoP and the NGOs and the terms of partnership between the NGOs and the beneficiary communities are settled.

There is a weak area of collaboration between the Government and NGOs. The capacity building programmes should be initiated both at grassroots institutional level and at government level. In this connection the following suggestions or policy reforms are recommended:

- All the CDGs should be linked as members of some active RSP or NGO of an area. This is very much needed for their social and technical guidance and rapid feedback.

- There should be horizontal and vertical linkages between government agencies, CDGs and respective RSP or NGO. These linkages should be at district, division and provincial level and if possible, for policy formulation and guidance, at the federal level. The active involvement of provincial and local government basis in this connection is strongly recommended.

- Each provincial government looks into the possibility of setting up an institutional mechanism, which would enable them to engage CDGs/NGOs in a dialogue and to coordinate planning and implementation of various CDG's activities at the field level. At district level "District Planning and Coordination Meeting" (DPCM) is recommended where all the stake holders conduct monthly meetings to plan, review and coordinate all development activities. This is the best forum for directing their field staff to co-ordinate with each other for an integrated way to serve the people. Similarly, at higher levels i.e. divisional, provincial and federal, parallel committees are formed. These committees would review the working of DPCM and guide them accordingly on a quarterly, biannaul and annual basis respectively.

- It is also suggested that orientation/sensitisation workshops and training be organised for provincial and district staff of government and the NGO community, in order to enhance mutual understanding of each other and thus foster greater collaboration between them on the ground.

- The local political and religious leadership also needs orientation about participatory development and the share of NGOs in order to hasten the process.

- The ineffective monitoring and evaluation (M\&E) system of government should be changed to the participatory result based M\&E system. 
- There is a serious need to have formal institutes that can provide diploma or degree programmes in Social Mobilisation (SM) in the country. Some initiatives taken by Extension Services Management Academy (ESMA), Garhi Dopatta, AJK to start one-year diploma programmes in SM are showing encouraging results.

- The job description of government line department officer and field staff at present has no mandate to work or co-ordinate with the CDGs/NGOs for service deliveries. Better linkages are recommended for effective delivery of services to end-user.

These reforms may be tested at a project/programme level where a reasonable number of households have been covered with SO. The government employees engaged and trained in the project should be placed for a certain fixed period. Frequent politically motivated transfers create serious setbacks.

\section{REFERENCES}

ADP-AJK (1997) Progamme Document. Area Development Programme Azad Jammu \& Kashmir, United Nations Development Programme, GoAJk

ADP-Balochistan (1998) Programme Document. Area Development Programme Balochistan. P\&DD, GoB.

AKRSP (1984) First Annual Review, 1983. Incorporating the Fourth Progress Report, Aga Khan Rural Support Programme, Gilgit, Northern Areas.

AKRSP (1999) Annual Report 1998. The Challenge of Poverty, Aga Khan Rural Support Programme, Gilgit, Northern Areas.

Awan, Manzoor-ul-Haque (1999) Northern Resources Management Project Lessons Learnt in Forestry Component. Workshop on Natural Resource Conservation through Participation, Department of Forest, GoAJK.

FAO (1993) Sustainable Development through Peoples' Participation. Inter-Regional Project for Participatory Upland Conservation and Development, FAO, Italiana, Gorkha, Nepal.

FAO (1998) Participatory Assessment, Monitoring and Evaluation Community Forestry Note 2. FAO, Rome, Italy.

Hassan, Asif (1999) We Should Form an East India Company. An article in the Daily “NEWS" dated October 17, Islamabad.

Jan, Ikramullah (1999) Concept Clarity of the Basic Terminology in SRSC's Perspective. Technical Paper-II, Sarhad Rural Support Corporation, Peshawar.

Khan, A. Hameed (1999) My View of Pakistan. An Article Reproduced in the Daily "NEWS" dated October 17, Islamabad.

Khan, Aurang Zeb (1999) Assessment of Bhimber Upland Rehabilitation and Development Project, Implementation Experience for Future Strategies. Workshop on Natural Resource Conservation through Participation. Department of Forest GoAJK. 
Khan, S. Sulatn, and Tariq Hussain (1984) Principles and Implementation for Small Farmers Development. The Pakistan Development Review 23.

Khan, S. Sultan, (1990) Institutional Development at the Grassroots . Concept Paper prepared for FAO, UNDP Projects PAK/87/008, Extension Services Management Academy, Garhi Dopatta, AJK.

LIFE (1998) Ham Nai Awam Sai Kya Sikha Ha (Urdu), Local Initiative for Urban Environement (LIFE), United Nation Development Programme, Islamabad.

Mustafa, U and M. Grunewald (1996) Monitoring and Evaluation with Emphasis on Cost/Benefit of Watershed Conservation Measures. Watershed Planning and Management Project Balochistan, Pakistan. GoB, Food and Agriculture Organisation of United Nations, Quetta/Borgholzhausen.

Mustafa, U. (1998) Monitoring and Evaluation Training Manual. Area Development Programme-AJK, UNDP, ESMA, Garhi Doppatta, AJK.

NRMP (1993) PC-1, Northern Resource Management Project. Department of Agriculture, Animal Husbandry, Forestry and Public Works, GoAJK.

NRSP (1995) Institutional Development at the Grassroots, Record of Proceedings of the Training Course November 26 to December 11, 1994. National Rural Support Programme/UNDP, Islamabad.

NRSP (1999) Fifth Annual Report 1997-98. National Rural Support Programme, Islamabad.

Pakistan, Government of (1999) Economic Survey 1998-99. Finance Division, Economic Adviser's Wing, Islamabad.

Reid, Peter, and Ch. Haq Nawaz Khan (1996) A Framework for Community Extension in AJK. Northern Resource Management Project, Extension, Training and Adaptive Research, Department of Agriculture, GoAJK.

SRSC (1998) SRSC Annual Review, 1997. Harnessing People’s Potential. Sarhad Rural Support Corporation, Peshawar.

UNDP (1997) Role of NGOs as Partners for the Delivery of Development Services. Local Dialgoue Group of the Pakistan Consortium, Economic Affair Division, GoP. UNDP.

UNDP (1998) Area Development Programme, AJK. United National Development Programme (UNDP), Azad Jammu \& Kashmir, Muzafarabad. 